\title{
GRATUITY PURCHASING AT WINERIES: AN INVESTIGATION OF THE DETERMINING FACTORS
}

Published in the International Journal of Wine Business Research, 2007, 19(4), 239 - 256

\author{
Natalia Kolyesnikova, Ph.D.* \\ Department of Nutrition, Hospitality and Retailing \\ Box 41162 \\ Texas Tech University \\ Lubbock, Texas 79409-1162, USA \\ Tel: $++1806742-3077$ \\ Fax: ++1 806 742-3042 \\ E-mail: n.kolyesnikova@ttu.edu
}

Tim H. Dodd, Ph.D.

Department of Nutrition, Hospitality and Retailing Box 41162

Texas Tech University

Lubbock, Texas 79409-1162, USA

Tel: ++1 806 742-3031 (ext. 239)

Fax: ++1 806 742-3042

E-mail: tim.dodd@ttu.edu

Debra A. Laverie, Ph.D.

Department of Marketing

Rawls College of Business Administration

Box 42101

Texas Tech University

Lubbock, Texas 79409-2101, USA

$$
\text { Tel }++1806742-3953
$$

Fax $++1806742-2199$

Email: debbie.laverie@ttu.edu 


\title{
Gratuity purchasing at wineries: An investigation of the determining factors
}

\author{
Abstract \\ Purpose - Wine and accessories bought partly or fully out of a perceived need to repay services \\ received at a winery are defined here as gratuity purchasing. The purpose of the research is to \\ identify factors that predict gratuity purchasing at wineries. Specifically, the study investigates \\ the role of gratitude and obligation, along with other consumer characteristics, in purchasing. \\ Methodology/Approach - Winery visitors were sampled from six Texas wineries. A total of \\ 357 questionnaires were analyzed. Hierarchical multiple regression, correlation and factor \\ analyses were employed.
}

Findings - Gratitude and obligation were found strong predictors of purchasing at wineries. Visitors who feel grateful to personnel and/or obliged to buy wine are likely to spend more money at wineries. Involvement and knowledge also appear to be related to purchasing. Practical Implications - Since gratitude and obligation appear strong predictors of buying decisions, winery managers need to find ways to enhance visitor feelings of appreciation. Although developing a sense of obligation may have an impact on sales, obligation may also create feelings of not wishing to return. It is important for managers to consider the extent to which they would like to have people feeling obligated or guilty about making a purchase. Originality/Value -The research offers new insights into an understudied area of consumer behavior - the role of reciprocity in purchasing behavior. An innovative feature of this study is the development of a new instrument to measure gratitude and obligation.

Keywords - wine tourism, gratitude, obligation, reciprocity, purchasing

Paper type - Research paper 


\section{Gratuity purchasing at wineries: An investigation of the determining factors}

At the heart of marketing is a good understanding of target consumers, specifically motivations to purchase and consumer attitudes to a product category or a specific brand. The current study aims to add to knowledge about consumer purchasing decisions in the wine tourism context.

The importance of wine tourism as a major source of revenue has been recognized by many researchers (e.g., Hall et al., 2000) Wine tourism is big business across the United States and worldwide. According to the Winemakers Federation of Australia (2005), the estimated value of wine tourism in Australia is nearly $\$ 1$ billion. Wine Institute (2004) reports that tourism directly related to the wine industry in California results in expenditures of $\$ 1.3$ billion annually. These are two regions where wine tourism is a major source of regional economies and have been well established for a number of years. However, wine tourism is also developing in emerging markets, which have not been traditional wine making regions. The Texas Wine Marketing Research Institute reports that the substantial impact of the wine industry on the state economy is due to substantial expenditures in hospitality and wine tourism, which resulted in nearly \$222 million in 2006 (Texas Wine Marketing Research Institute, 2007).

Wine tourism is a significant source of revenue for many large and well-established wineries. Large California-based wineries, for example, rely on wine tourism as a sales channel, promotion for business, and means for educating customers (Moulton and Lapsley, 2001). For many small wineries, however, tourism is the core business and a key factor for viability of their production. This is especially true for emerging wine regions. For instance, in Texas eighty percent of all wineries are small businesses with less than ten thousand gallons of annual wine production (Dodd et al., 2004). These wineries often do not have sufficient production to 
distribute through wholesale or retail channels. Therefore, small wineries are the most dependent on sales at their premises. Tourism becomes exceptionally important to such wineries in terms of their ability to sell wine either directly to visitors through their tasting rooms or to place customers on a direct mail order list.

Small wineries are usually independent, family-owned businesses. They are typically managed by one or two people undertaking all the management functions without the assistance of paid expertise. It has been noted in wine marketing literature that sometimes these small businesses fail to recognize the importance of marketing (Hall et al., 2000, Macionis and Cambourne, 1998). Spawton (1986) pointed out that the lack of profit in the wine industry was due to preoccupation within the industry with "making and selling rather than applying marketing concepts to winemaking activities" (p. 89). An understanding of wine tourists' purchasing behavior can help provide important insights for wineries managers.

Consumer purchasing behavior is a complex issue. Sometimes purchasing can be explained simply by objective characteristics of the product, for example the price of wine. Subjective consumer preferences are also likely to have considerable impact on purchasing decisions. Such preferences may include perceptions of the atmosphere in the tasting room, enjoyment of the tour or taste of wine. In many instances, however, the real reasons for purchasing may be obscure and difficult to identify. To illustrate, visitors to wineries may feel grateful to winery personnel for the services received. These feelings of gratitude may trigger a desire to buy wine in order to show appreciation to those who provided the services. Alternatively, feelings of obligation (rather than gratitude) may be dominant. The sense of obligation may result from the free tasting and hospitality offered at the winery. The study 
reported herein aims to investigate feelings of gratitude and obligation that potentially may prompt purchasing at wineries.

Gratitude and obligation may lead to what we suggest to be called gratuity purchasing. In a general sense, gratuity means something (usually money) given voluntarily, often in return of favor or services. The amount typically depends on the inclination of the giver. purchases then are products or services bought by consumers fully or partly due to a perceived need to repay benefits received from a business or its employees.

Although research on wine tourists has expanded in recent years (Bruwer, 2003, Charters and Ali-Knight, 2002, Mitchell et al., 2000, Yuan et al., 2005), in the extant literature we are not aware of another study which examined the sociological perspective of winery visitor behavior. The current study aims to explore whether or not winery visitors buy wine due to a perceived need to repay services received at a winery. Specifically, the study examines the effect of gratitude and obligation on wine tourist purchasing behavior.

\section{Theoretical Background}

Gratuity purchasing can be theoretically supported by a concept that has been long known in social psychology as reciprocity. The norm of reciprocity traces its roots to Gouldner (1960) who claimed that for a social system to be stable there must always be some "mutuality of gratification" (p. 168). In a very basic form, the reciprocity rule posits that people feel obligated to repay, in kind, what other people have provided them. For example, when a person gives us a gift, we often feel we should give him/her a gift in the future. If somebody helps us, we feel a need to repay the kindness later. According to the reciprocity norm then, people feel an emotional need to reciprocate for positive behavior received. The current research will apply reciprocity theory to examine its relevance to the consumer behavior context. 


\section{Gratitude and Obligation}

In his original theory, Gouldner (1960) suggested that the two conditions that make the reciprocity rule work are gratitude and obligation. In social psychology literature, gratitude has been defined as the positive affective response to receiving a benefit or a favor (Fitzgerald, 1998, Emmons and Crumpler, 2000). In contrast, obligation is typically considered a negative, possibly uncomfortable state which is determined by normative demands and can be perceived aversive (Greenberg and Bar-Tal, 1976, Greenberg and Shapiro, 1971).

Despite the obvious conceptual differences between gratitude and obligation, operational differentiation between the two terms is not always straightforward. It is not until recently that attempts have been made to differentiate the operationalization of the constructs (Goei and Boster, 2005). Their results suggested that gratitude and obligation not only can be distinguished conceptually, but also should be approached as two separate constructs. In the current study, we intend to further explore the dimensionality of the gratitude and obligation constructs.

Many scholars acknowledge that gratitude and obligation can operate independently and attempts have been made to investigate the impact of each factor on reciprocal behavior. Previous studies focused mainly on the relationship between receiving a favor and compliance with further requests from the favor-giver. There is empirical evidence that gratitude predicts reciprocal actions (Emmons and McCullough, 2003, Graham, 1988, Goei and Boster, 2005). The studies on obligation, on the other hand, provided inconsistent results. Some studies have found providing favors increases obligation, and obligation, in turn, increases compliance (Greenberg and Saxe, 1975, Greenberg and Frisch, 1972). Other studies reported no relationship between obligation and subsequent compliance (Goei and Boster, 2005). 
The favor-compliance link, with the accompanying mediating role of gratitude and obligation, was an important foundation of the current study. This research aims to empirically test gratitude and obligation from the consumer behavior standpoint. In a pure sense, services at wineries are not a favor, and purchasing wine is not compliance. However, some conceptual parallel can be drawn between purchasing behavior at wineries and the favor-compliance link. Obviously, consumers do not perceive services at wineries as favors. It is reasonable to expect quality service. Yet, if visitor expectations were met (and especially if they were exceeded) visitors may feel appreciative of the staff who provided services. Most people have a natural tendency to feel an urge to reciprocate to those who assist them (Whatley et al., 1999). In a way, feelings of gratitude while at a winery are similar to those feelings that people experience when receiving a favor - that is, appreciation of those who treated them kindly.

Following the same reasoning, purchasing is not an equivalent of compliance. However, at least subconsciously, visitors understand that the seller will benefit if they purchase wine. In view of the reciprocity norm, the exchange of benefits should be mutually beneficial. So, on the one hand, consumers may see purchasing as a way to express their gratitude. Alternatively, purchasing can occur due to a perceived need to comply with the reciprocity norm, especially since "the exchange of benefits" takes place in public conditions. In summary, there are good theoretical reasons to believe that gratitude and obligation may impact winery visitors' purchasing behavior.

\section{Relevant Consumer Behavior Attributes}

The existing research on favor-compliance relationships focused mainly on the effects of gratitude and obligation, with virtually no reference to personality characteristics that can potentially increase or decrease the likelihood of reciprocal actions. Theoretically, the extent to 
which an individual feels grateful or obliged can be determined by almost anything, from family traditions to the relationship between the beneficiary and the benefactor. However, one can rationally limit the number of such factors to fit the scope of the particular research. In the present study, attributes that reflect consumer overall interest in wine are expected to impact consumer levels of gratitude and obligation. The effect of product involvement, purchase involvement, product knowledge, and identity on gratuity purchasing at wineries are also examined.

\section{Product Involvement}

The decision to select product involvement as a variable of interest was supported by the demonstrated relevance of involvement in wine tourism and marketing. Previous research has found that depending on the level of involvement, wine consumers significantly differ on their purchasing quantities (Lockshin et al., 1997, Quester and Smart, 1998), perceptions of services at wineries (Dodd and Gustafson, 1997), wine consumption (Goldsmith et al., 1998), preferences of region, grape variety and price (Zaichkowsky, 1985), interest in brands, as well as satisfaction, store and salesperson trust (Lockshin et al., 2001). Since high and low involved wine consumers were found to differ on many aspects, their levels of gratitude and obligation may be different as well. It is expected that product involvement can affect gratuity purchasing at wineries.

\section{Purchase Involvement}

Although consumer involvement with a product category has been found explanatory for purchasing decisions, consequences of a right choice of a particular purchase can be equally important. Depending on a situation, a product can take on a different degree of relevance for a person. Consider different levels of importance that customers may assign to selecting a wine to 
be consumed during a regular family dinner at home as opposed to a wine to be served at a dinner party they are hosting.

In the study reported herein, purchase involvement is investigated separately from product involvement. We suggest that purchase involvement may influence gratuity purchasing independently from other factors. To illustrate the difference between product and purchase involvement in terms of gratitude, consider two winery visitors. One is a highly involved wine consumer, while the other is less involved, but is very concerned with the outcome of the particular purchase (e.g., looking for a wine to give as a gift to someone special). The first visitor may appreciate, for example, special varietals that can be found only at a specific winery. The second visitor may not be concerned about special wines, but feel grateful for a recommendation from the personnel which facilitates his/her task to purchase wine. Purchase involvement then can lead to feelings of gratitude as much as product involvement.

\section{Product Knowledge}

The significance of product knowledge in purchasing wine has been recognized by many researchers (Gluckman, 1990, Spawton, 1991, Dodd et al., 2005). Highly involved consumers usually seek additional information about the product and thus become more knowledgeable. For the purposes of this study, the knowledge construct was limited to consumer self-assessed knowledge about wine (subjective knowledge). Subjective knowledge was found a better predictor of purchasing decisions than objective knowledge (Raju et al., 1995). These findings were also supported in wine marketing (Dodd et al., 2005). The current research focused more on visitor perceptions of their knowledge about wine rather than their factual knowledge. Therefore, visitor subjective knowledge appeared suitable for the context of investigation.

\section{Identity}


In essence, identity refers to a concept of self composed of the multiple roles we play in society (Stryker, 1968). One's self is a combination of different roles one personalizes. For example, one may have identities of an insurance agent, husband, sport memorabilia collector, cyclist, and wine enthusiast. This approach has been demonstrated to be more meaningful than the historical "global self" approach (Laverie et al., 2002).

Researchers often take the identity salience approach when examining the concept of identity (Callero, 1985, Hoelter, 1983, Shamir, 1992, Laverie and Arnett, 2000). According to this approach, also known as identity theory (Stryker, 1968, Stryker, 1980), identities are arranged hierarchically, meaning that under certain circumstances, some become more important (i.e., salient) than others. For example, when given a choice, a person who assigns more importance to a wine consumer identity would more likely spend time reading wine magazines, visiting wineries, shopping for wine accessories or simply enjoying wine. Previous research found identity salience to play an important role in consumer behavior (Arnett et al., 2003, Laverie, 1998, Laverie and Arnett, 2000).

In the present study, we focus on the wine tourist identity. To differentiate, a broad wine consumer identity suggests that wine is an important part of one's self; a wine tourist identity is also associated with wine, but in addition it encompasses a number of wine tourism related activities, such as visitations to wineries, vineyards, wine festivals, etc. In this study, identity salience was approached as a behavioral characteristic that represents commitment to a wine tourist role. It is expected that while at a winery, visitor identities as wine tourists become salient, and when combined with a perceived norm to reciprocate, may predict visitor purchasing decisions. 
Due to the exploratory nature of the present research, the problem under investigation is stated as a complex research question. Specifically - do gratitude, obligation, product involvement, purchase involvement, product knowledge, and identity salience predict visitor purchasing at wineries?

\section{Method}

\section{Sample and Procedures}

The population of interest is visitors to wineries. Six wineries geographically dispersed throughout the state of Texas were used as sites to gather data. Texas was selected as an appropriate location to conduct tasting room studies for a variety of reasons. Texas is the $5^{\text {th }}$ largest wine producer in the United States with over 120 wineries and is in a rapid growth phase. It is similar to many other states and regions around the world that have started development during the past 30 years and where wine tourism has played a prominent role in their growth.

Texas has a variety of winery types, with some large upscale facilities with substantial staff involvement to small sheds where the owner is the wine maker, tour guide, and involved in all aspects of the business. For the current study, a conscientious effort has been made to include different types of wineries based on winery size, product specialization, and reputations. There was also a range of wine prices at the chosen wineries which added to the diversity of the data collection sites. Some of the wineries had wines priced up to $\$ 50$, while others had a range of $\$ 10$ to $\$ 15$. These price ranges are typical for Texas wineries with respect to tasting room prices where the majority of their products are sold through the tasting room.

Data collection was conducted during the weekends over a three-month period. One researcher personally distributed questionnaires at the wineries. Respondents then completed the 
questionnaire before leaving the winery. Initially, a total of 371 questionnaires were collected. After eliminating incomplete questionnaires, 357 cases were left for data analysis.

The sample consisted of slightly more women $(n=191)$ than men $(n=166)$ and the average age of respondents was 41 years. Seventy-three percent were under 51 years of age. Notably, $18.5 \%$ were younger consumers, 21 to 30 years old. Respondents had high levels of education with two-thirds of the sample having earned either an undergraduate or graduate degree. Only 5.6\% had not attended college. Participants' income levels were substantially higher than the general U.S. population. Almost one-third reported that their annual household income exceeds $\$ 100,000$. For comparison, the median income of the U.S. population in 2005 was $\$ 46,326$ (U.S. Census Bureau, 2006). The majority (58\%) of respondents’ occupations were either professional/technical (e.g. engineers, architects, lawyers, doctors, teachers, scientists) or executive/managerial (e.g., accountants, managers, administrators). Overall, the sociodemographic background of visitors to Texas wineries (middle-aged, educated, with higher incomes) mirrored the profile of wine consumers in general (MKF Research, 2000).

\section{Measures}

Some of the constructs used in the study have long been subjects of investigation in marketing research. For instance, an extensive literature and a number of reliable scales were available for the involvement, knowledge, and identity measures.

Product involvement was operationalized via the Personal Involvement Inventory (PII) scale originally developed by Zaichkowsky (1985). The modified version of PII (Mittal, 1995) was used in this study. The indicators of product involvement were "unimportant /important, means nothing to me/means a lot to me, insignificant/significant, does not matter to me/matters to me," each assessed by a seven-point bipolar scale. Ratings on the four items were averaged to 
generate the overall mean score for the product involvement measure. A higher number indicated higher product involvement.

Purchase involvement measure was adapted from the Purchase Decision Involvement scale (PDI) (Mittal, 1995). Respondents reported the importance of the particular purchase on three items, each measured on a seven-point Likert scale: "In choosing from the types of wine available at [winery name] today, would you say that you would not care at all as to which one to buy / would care a great deal as to which one to buy"; "How important is it for you to make a right choice of wine today?"; and "How concerned are you about the outcome of your choice of wine today?" An overall mean of the three items was used as a measure of participants' purchase involvement. Higher numbers represented higher purchase involvement.

Product knowledge was measured using a scale developed by Park, Mothersbaugh, \& Feick (1994). Respondents' self-reported assessment of product knowledge was measured on three items: "How much do you feel you know about wine?"; "Compared to your friends and acquaintances, how much do you feel you know about wine?"; and "Compared to a wine expert, how much do you feel you know about wine?" Each item was administered on a seven-point Likert scale anchored between very little (1) and very much (7). For data analysis, scores on the three items were collapsed and averaged.

Identity salience was measured with a scale developed by Callero (1985). The original scale measured identity salience related to blood donating. Therefore, it was necessary to adapt the items to reflect the context of the present study. To measure participants' perception of themselves as wine tourists, four items were used, each measured on a seven-point scale with strongly disagree (1) and strongly agree (7) as anchors: "Visiting a winery is something I rarely think about" (reverse coded); "For me, visiting a winery means more than just drinking wine"; 
"Visiting wineries is an important part of who I am"; and "I really don't have any clear feelings about visiting wineries" (reverse-coded).

Existing self-administered measures of gratitude and obligation were mostly in the area of social psychology. No scale was located that could be directly applied to the current study. Therefore, a multi-item scale was developed to measure the degree of gratitude and obligation experienced by winery visitors.

For the instrument development, a pretest was initially administered to 59 undergraduate students at a large public U.S. southwestern university. The purpose of the pretest was to obtain a comprehensive list of antecedents to gratuity purchasing. Simulated scenarios were developed to create situations similar to visiting a winery in terms of generating feelings of gratitude and obligation. One scenario featured a visit to a brewery with beer tasting and a tour; the other described a visit to a department store, where a make-up consultant offers a free make-over. Both scenarios ended with the same list of open-ended questions. Based on the content analysis of the responses, an initial list of factors that could potentially lead to gratuity purchasing was developed.

The researchers then employed a second pretest to ensure the power of the items. A focus group was conducted with twelve people who visited several wineries in the past. Given that gratuity purchasing may be of subconscious nature, questions about gratitude, obligation, and other factors related to gratuity purchasing were asked directly and indirectly.

Using the pretest scenarios and the focus group analyses, a final list of items to measure gratitude and obligation was developed. Three items measured positive affective response to visiting a winery, namely (a) desire to say "thank you" to winery personnel, (b) appreciation of the wine tasting, and (c) appreciation of the tour. Other items measured a negative, possibly 
uncomfortable, state that visitors may experience, namely (a) feelings of ethical indebtedness to buy wine, (b) purchase expectation from the winery personnel, and (c) normative pressure ("buying wine is the socially proper thing to do"). A seven-point Likert-type response scale was used to measure factors that may affect purchasing with least likely (1) and most likely (7) as anchors.

Purchasing at wineries was measured using a two-item scale. Respondents reported a dollar amount spent on wine and on items other than wine (wine accessories). Seventy-five percent of the sample purchased wine and/or accessories, while $25 \%$ did not make a purchase. Wine sales per person had a mean of $\$ 27.37$ (90.4\% of sales per person), while accessories sales per person accounted for an average of $\$ 2.92(9.6 \%$ of sales per person). For data analysis, the total spending (i.e., a combined amount spent on wine and accessories) was used as a measure of purchasing. The mean of the total amount spent at the wineries was about thirty dollars $(M=$ $30.29, S D=34.39$ ); the median was $\$ 20.00$.

\section{Data Analysis}

\section{Dimensionality of Constructs}

To determine the underlying structures of the newly developed gratitude and obligation scale, the measure was subjected to the principal axis factoring with varimax rotation. An examination of factor loadings, eigenvalues greater than one, and the scree plot suggested two factors. The first factor was defined by three loading values that were related to positive affective responses to receiving services at a winery, namely (a) desire to say "thank you" to winery personnel, (b) appreciation of the wine tasting, and (c) appreciation of the tour. We labeled this factor gratitude. The second factor was composed of three items that had more obligatory meaning, namely (a) ethical indebtedness to buy wine, (b) purchase expectation from winery 
personnel, and (c) normative pressure ("I feel that buying wine is a socially proper thing to do"). We labeled this factor obligation. The two factors accounted for $55.67 \%$ of the total variance. Correlation analyses revealed that the items on each factor showed a high degree of internal consistency indicating that the three items on each factor were measuring a single, similar construct. Cronbach's alpha $(\alpha)$ for the gratitude factor was .87 ; for the obligation factor $\alpha=.73$. The results of the factor analysis were consistent with previous research on dimensionality of the gratitude and obligation constructs (Goei and Boster, 2005) and again confirmed that gratitude and obligation can be operationally differentiated.

The same factor-analytical procedures were performed to generate factor structures for product involvement, purchase involvement, product knowledge, and identity. Four constructs comprised of sixteen items were subjected to principal axis factoring utilizing varimax rotation. The sixteen items loaded into four factors, all meeting the minimum Cronbach's coefficient reliability of .70 indicating internal consistency of the following factors: product involvement ( $\alpha$ $=.97)$, purchase involvement $(\alpha=.89)$, product knowledge $(\alpha=.91)$, and identity $(\alpha=.78)$. The four factors accounted for $72.93 \%$ of the total variance. Based on the results of the factor analysis, gratitude, obligation, product involvement, purchase involvement, product knowledge, and identity were accepted for subsequent use as independent variables in the multiple regression analysis.

\section{Correlation Analysis}

Correlation analysis revealed no signs of high correlation between the independent variables, except for a relatively high correlation between product knowledge and product involvement $(r=.74, p<.01)$. These findings are hardly surprising. Usually highly involved consumers tend to seek more information about the product and therefore, possess higher levels 
of knowledge than low involved consumers. Despite the high correlation between product involvement and knowledge, the decision was made to retain both variables in the regression analysis because the correlation appeared appropriate. Furthermore, the two constructs loaded on two separate factors. Collinearity diagnostics revealed no evidence of multicollinearity between the two variables.

Gratitude significantly and positively correlated with product involvement and knowledge ( $r=.15, p<.01 ; r=.18, p<.01$, respectively). Contrary to gratitude, the direction of the relationships between obligation and other variables was negative. Obligation significantly and negatively correlated with product involvement $(r=-.15, p<.01)$, purchase involvement $(r$ $=-.13, p<.05)$, knowledge $(r=-.11, p<.05)$, and identity $(r=-.15, p<.01)$.

With reference to the relationship between the dependent and the independent variables, total spending at wineries significantly and positively correlated with all six independent variables. Correlation between gratitude and total dollars spent was the highest $(r=.51, p<.01)$, followed by correlation between obligation and total spending $(r=.36, p<.01)$. Total spending also significantly correlated with both product and purchase involvement $(r=.32$ and $r=.23$, respectively, $p<.01)$, knowledge $(r=.32, p<.01)$, and identity $(r=.21, p<.01)$.

\section{Multiple Regression Analysis}

Hierarchical multiple regression was employed to predict visitor purchasing at wineries. The criterion variable was purchasing (i.e., total dollars spent). The predictor variables were divided into two sets. The first set of predictors included product involvement, purchase involvement, product knowledge, and identity, while the second set included gratitude and obligation. The decision to separate the predictors into two sets was based on conceptual differences between the factors. 
Involvement, knowledge, and identity are consumer characteristics which represent the importance of wine and wine tourism in visitors' lives. In contrast, gratitude and obligation are not related to visitor interest in wine. These feelings are primarily associated with perceptions of services and winery personnel. Visitors may or may not experience gratitude and obligation, regardless of the significance of wine in their lives. However, we expect that when combined with involvement, knowledge, and identity, gratitude and obligation may enhance visitors' decision to buy wine. The six constructs were included in the regression analysis as independent variables

The regression analysis was conducted in two steps to determine how well each set predicts the criterion over and above the other set. The first step was used to evaluate whether involvement, knowledge, and identity predict purchasing at wineries. The four measures accounted for a significant proportion of the purchasing variability, $R^{2}=.12$, adjusted $R^{2}=.11$, $F(4,351)=12.28, p<.01$

After controlling for the level of involvement, knowledge, and identity, the change in $R^{2}$ associated with adding the second block of variables was examined to evaluate the incremental value of gratitude and obligation. The change of $R^{2}$ from the first set to the second set was statistically significant, $R^{2}$ change $=.24, F(2,349)=64.59, p<.01$. These results suggest that gratitude and obligation explain $24 \%$ of the unique variance in the criterion variable. Totally, the six predictor variables accounted for $36 \%$ of the variance in the dependent variable. Overall results of the hierarchical regression are presented in Table I.

\section{Insert Table I about here}

The coefficient matrix was further examined to evaluate contributions of the individual predictors. Gratitude and obligation were found the most influential predictors of purchasing $(\beta=$ 
$.34, \beta=.22$, respectively). Coefficients for product and purchase involvement, as well as for product knowledge, were also significant. Although a significant relationship between purchasing at wineries and wine tourist identity was expected, none was found. Coefficients for each predictor in the regression analysis are presented in Table II.

\section{Insert Table II about here}

\section{Discussion}

The study investigated whether gratitude, obligation, involvement, knowledge, and identity can predict visitor decisions to purchase wine and/or wine accessories at wineries. The results indicate that out of the six independent variables entered into the regression analysis, five were found predictors of how much visitors will spend. These predictors are gratitude, obligation, product and purchase involvement, and product knowledge. Identity salience was not discriminated as an independent significant predictor of purchasing.

Both gratitude and obligation accounted for a significant amount of purchasing variability, indicating that those visitors who feel gratitude and obligation while visiting wineries will spend more money on wine and/or accessories. Moreover, gratitude and obligation were found the strongest predictors of purchasing. Therefore, gratitude and obligation are positively associated with the amount of money visitors spend at wineries.

Involvement (both product and purchase) and product knowledge can also predict purchasing. Stated otherwise, higher levels of product involvement, purchase involvement, and product knowledge predict larger expenditures at wineries.

Contrary to our expectations, identity was not found to be a statistically significant predictor of purchasing. General descriptives analysis suggested that wine tourist identity was important to visitors $(M=4.57, S D=1.51)$. In addition, identity positively correlated with the 
amount of money spent at wineries $(r=.21, p<.01)$, meaning that the higher the identity as wine tourists, the higher the expenditures at wineries. However, when combined with the other predictor variables, identity did not contribute significantly to purchasing. It appears that the relationship between identity salience and expenditures at wineries was mediated by the relationship between other factors and total dollars spent at tasting rooms. Perhaps, the other independent variables were stronger predictors of purchasing and surpassed the power of identity.

Additional results suggest that as the level of involvement, knowledge, and identity increases, the level of obligation decreases. This negative relationship between obligation and wine consumer characteristics seems reasonable. Highly involved and knowledgeable consumers, as well as those who identify themselves as experienced wine tourists, are usually more discriminating in their choices. For such visitors, certain aspects of their visits to wineries are particularly important (e.g., assortment of wines, highly educated winery personnel). Since their priorities are set differently from those of less involved visitors, highly involved visitors feel less obliged to buy wine. Typically, their expectations of services at wineries are high. Unless those expectations are met or exceeded, highly involved and knowledgeable visitors are unlikely to feel obligated to buy wine.

In contrast to obligation, higher levels of involvement, knowledge, and identity did not seem to lower levels of gratitude. Our results suggested that the higher the levels of involvement, knowledge, and identity, the more grateful visitors are. It appears that if highly involved and knowledgeable visitors are satisfied with their experiences at a winery, they feel appreciation to the winery personnel and are likely to buy wine.

\section{Managerial Implications}


This study provides managers with new insights to develop better marketing strategies. Winery managers need to be aware that in addition to product characteristics (e.g., quality, price, variety, vintage, etc.) customers purchasing decisions may be driven by less obvious factors, such as those investigated in this study - feelings of gratitude and obligation. This understanding will lead to a more critical look at marketing strategies aimed at establishing relationships with a customer. Winery marketing efforts need to be analyzed through the prism of the gratuity purchasing concept. In the short term, every marketing opportunity (e.g., atmosphere at a winery, signage, etc.) needs to be evaluated critically as to what emotional response it is creating. Winery marketing strategies need to be directed at generating feelings of gratitude and it may not be appropriate to make a customer feel obliged. It is particularly important for managers to consider this perspective when conducting training for employees who are involved with face-toface interaction with customers. In the long term, focus needs to be placed on those marketing efforts that have potential to increase the gratitude component of the winery-customer relationships (e.g., mailing lists, wine clubs)

Since feelings of gratitude appear such a strong predictor of buying decisions, winery managers need to find ways to enhance customer positive emotional response. Visitors' experiences at wineries need to be enjoyable at the minimum for gratitude to occur.

The most effective way to generate gratitude is through high quality customer service. Several studies on restaurant tipping found a statistically significant positive relationship between tip sizes and service quality (Lynn and Graves, 1996, Lynn and Grassman, 1990). These findings are consistent with the underlying premise of this study suggesting that equity benefit motivations operate in business-consumer relationships. Larger tip size reflects service quality, 
which results from feelings of appreciation of the server. Similarly, quality services at a winery trigger feelings of gratitude, which, in turn, leads to larger expenditures.

While customer service is an important factor for winery businesses, building relationships with customers should be the long-term objective. As marketers move towards oneto-one marketing, winery managers will need to focus on cultivating relationships with customers to ensure the success of retail sales at the winery. By building long-term relationships, wineries can maximize the lifetime value of a loyal customer. Winery managers should focus on developing customer equity, the value of the customer relationships (Rust et al., 2000). Once these relationships are developed, it is likely that the consumer feels gratitude toward the winery and will be more likely to continue to make purchases at the winery.

In today's highly competitive business world, customers have more choices of where to spend their time and money. As an illustration, wine prices are typically higher at wineries than at retail stores and even if visitors like the wine they tasted, they may still decide not to visit the winery. Instead, they may decide to purchase the wine later at a grocery or liquor store. Thus, winery managers need to ensure visitors enjoy their visits to the tasting room, and not merely enjoy the wine.

Customer expectations should no longer be simply met, but need to be exceeded in order for customers to feel gratitude and appreciation. With more people becoming interested in wine, one outcome visitors may expect from visiting a winery is learning more information about the product. Many people admit that they have a lack of confidence when choosing wine and are afraid to appear unknowledgeable when discussing wine. Any marketing effort from winery management offering reassurance is likely to win consumer support as customers are looking for knowledgeable winery personnel at tasting rooms. At the same time, people who work at 
wineries should be careful not to appear superior in their knowledge. Visitors will feel appreciation only when they feel genuine warmth and hospitality. The tasting rooms managers need to assure that their customers leave with positive attitudes towards the winery and its wines.

Obligation to repay services at wineries was also found a strong predictor of purchasing. Even though developing feelings of obligation may have an impact on sales, obligation may also create feelings of not wishing to return. It may be important for winery managers to consider the extent to which they would like to have people feeling obligated or guilty about making a purchase. For some wineries just interested in making short-term sales this may not initially impact them if they have a constant stream of new customers. In fact obligation may help to increase the bottom line through increasing per customer sales. However, potential negative feelings are likely to correspond with negative word-of-mouth referrals and a lack of interest in repeat visits. This would also be something that could be further examined in additional research projects.

The results of this study were specific to tasting room visits. However, there might also be implications for other contexts. For example, the gratuity purchasing concept can be applied to museum tours, which typically end at a gift shop. This marketing strategy is usually implemented on the basis of business intuition. However, understanding that marketing efforts should be directed at inducing an emotional appeal of gratitude opens a new perspective on consumer behaviour and allows marketing efforts to be more purposeful.

The findings can also be applied to a restaurant setting. As mentioned earlier, a conceptual parallel can be drawn between restaurant tipping and gratuity purchasing since both reflect on the level of customer satisfaction with services. In addition, a recent study on wine promotions in 
restaurants (Wansink et al., 2006) found that offering wine-food pairing recommendations in a restaurant setting appears to be most effective when used with limited number of wines. The researchers suggested implementing wine-food pairing recommendation for no more than three or four wines. Since this is approximately an average number of tastings at a winery, one possibility is for wineries to implement food-wine pairing recommendations at their premises. This strategy may add to the gratitude component of customer emotional response.

Although beyond the scope of this research, it may also be possible that when visitors feel appreciative, not only do they spend more money on wine, but their feelings of gratitude may carry over to customer loyalty. A visit to a tasting room may become a foundation for deeper relationships between the winery and its customers. Customer loyalty is the key objective for winery management as repeat customers tend to spend more money on subsequent visits.

\section{Limitations and Future Research}

The current study was an initial investigation of the effect of reciprocity on purchasing behavior in the wine tourism context. The research answered a number of questions concerning the role of gratitude and obligation in purchasing at wineries, but there is considerable room for further investigation of these issues.

One limitation to the present research revolved around the sampling method. Texas is not a traditional wine region and the state wine industry is still in its developing stage. Inferences drawn here may be region specific. Generalizations to other wine tourism sites are not yet warranted. For example, customer attitudes towards Texas-made products could be a potential mediating factor that influences levels of gratitude and obligation. Texans can be very loyal towards products made in their state. Loyalty, in turn, could carry over to a desire to support local wineries which may also influence gratuity purchasing. Although careful efforts have been 
made to include different types of wineries into the sample, conducting the study in more established wine regions such as California may add different factors into consideration.

To increase the generalization of the results, replication of this research in a variety of settings is recommended. There might be significant variations in findings depending on the place of data collection, especially if a multicultural study is conducted. Wine consumers from other countries may experience different levels of gratitude and obligation while visiting wineries. It is possible, for example, that the effect of obligation has been influenced by the U.S. tipping culture. Conducting the study in another country, where tipping is not an integral part of culture, may provide different results.

The suggested approach to purchasing behavior through reciprocity can also be used in other research contexts. To add to empirical evidence of the reciprocity norm, extension of this study to other areas such as hospitality or retailing is highly recommended.

An additional issue associated with the sampling method is the fact that most Texas wineries are independent, privately-owned businesses. Winery owners often make their own wines, as well as perform all the operations related to the tasting room management. While visiting a winery, consumers directly communicate with people who personally made the wine they taste. In many cases, visitors can feel a special bond between the wine maker and the wine. This atmosphere can enhance senses of appreciation of the host and possibly lead to the sense of obligation to buy. It is not clear if the results of this study can be generalized to other types of wineries. Comparison between visitors of privately and publicly owned wineries can bring new insights into research on reciprocity. 
One possible expansion of this study is including winery managers in the methodology in order to create a direct relationship between theory and application. In-depth interviews and/or focus groups would add more value to the investigation of the subject.

Finally, limitations associated with the measurement tools should be noted. This research was one of the first consumer behavior studies which aimed to quantitatively measure gratitude and obligation in consumer behavior. Although the new instrument performed reliably in the present study, additional efforts should be made to further refine the instrument in order to increase its validity and reliability. Using the instrument in various settings is recommended.

\section{Conclusions}

The purpose of the study was to investigate the role that gratitude and obligation, in combination with other consumer characteristics, play in wine and/or wine accessories purchases at wineries. The results empirically supported reciprocity theory and previous experimental evidence that people feel appreciation and a need to reciprocate for positive behavior received. The study demonstrated that gratitude and obligation, widely investigated concepts in psychology and sociology, are also applicable to consumer behavior. Gratitude and obligation were found strong predictors of visitor purchasing behavior at wineries. When customers feel thankful to the personnel for the time spent with them providing a tour, wine tasting, and other educational assistance, they may feel that buying a bottle of wine is the least they can do to repay the hospitality. Visitor involvement with wine (both product and purchase) and product knowledge also appear to predict purchasing at tasting rooms. To summarize, this research not only adds to knowledge about wine consumers, but also offers new insights into the understudied area of consumer behavior research - the effect of the reciprocity norm on purchasing behavior. 


\section{References}

Arnett, D. B., German, S. D. and Hunt, S. D. (2003), "The identity salience model of relationship marketing success: The case of nonprofit marketing", Journal of Marketing, Vol. 67 No. 2, pp. 89-105.

Bruwer, J. (2003), "South African wine routes: Some perspectives on the wine tourism industry's structural dimensions and wine tourism product", Tourism Management, Vol. 24 No. 4, pp. 423-35.

Callero, P. L. (1985), "Role-identity salience", Social Psychology Quarterly, Vol. 48 No. 3, pp. 203-15.

Carlsen, J. and Charters, S. (2006), Global wine tourism: Research, management and marketing. CABI Publishing, Oxfordshire, UK

Charters, S. and Ali-Knight, J. (2002), "Who is the wine tourist?" Tourism Management, Vol. 23 No. 3, pp. 311-19.

Dodd, T. H. and Gustafson, A. W. (1997), "Product, environment, and service attributes that influence consumer attitudes and purchases at wineries", Journal of Food Products Marketing, Vol. 4 No. 3, pp. 41-59.

Dodd, T. H., Kolyesnikova, N. and Revilla, G., (2004), A profile of the Texas wine and wine grape industry, Texas Wine Marketing Research Institute Pub. No. 04-01. Texas Tech University, Lubbock, TX.

Dodd, T. H., Laverie, D. A., Wilcox, J. F. and Duhan, D. F. (2005), "Differential effects of experience, subjective knowledge and objective knowledge on sources of information used in consumer wine purchasing", Journal of Hospitality and Tourism Research, Vol. 29 No. 1, pp. 3-19.

Emmons, R. A. and Crumpler, C. A. (2000), "Gratitude as a human strength: Appraising the evidence", Journal of Social and Clinical Psychology, Vol. 19, pp. 56-69.

Emmons, R. A. and McCullough, M. E. (2003), "Counting blessings versus burdens: An experimental investigation of gratitude and subjective well-being in daily life", Journal of Personality and Social Psychology, Vol. 84, pp. 377-89.

Fitzgerald, P. (1998), "Gratitude and justice", Ethics, Vol. 109, pp. 119-53.

Gluckman, R. L. (1990), "A consumer approach to branded wines", International Journal of Wine Marketing, Vol. 2 No. 1, pp. 27-46.

Goei, R. and Boster, F. J. (2005), "The roles of obligation and gratitude in explaining the effect of favors on compliance", Communication Monographs, Vol. 72, pp. 284-300. 
Goldsmith, R. E., d'Hauteville, F. and Flynn, L. R. (1998), "Theory and measurement of consumer innovativeness: A transnational evaluation", European Journal of Marketing, Vol. 32 No. 3/4, pp. 340-53.

Gouldner, A. W. (1960), "The norm of reciprocity: A preliminary statement", American Sociological Review, Vol. 25 No. 2, pp. 161-78.

Graham, S. A. (1988), "Children's developing understanding of the motivational role of affect: An attributional analysis", Cognitive Development, Vol. 3, pp. 71-88.

Greenberg, M. S. and Bar-Tal, D. (1976), "Indebtedness as a motive for acquisition of "helpful" information", Representative Research in Social Psychology, Vol. 7, pp. 19-27.

Greenberg, M. S. and Frisch, D. M. (1972), "Effect of intentionality on willingness to reciprocate favor", Journal of Experimental Social Psychology, Vol. 8, pp. 99-111.

Greenberg, M. S. and Saxe, L. (1975), "Importance of locus of help initiation and type of outcome as determinants of reactions to another's help attempt", Social Behavior and Personality, Vol. 3, pp. 101-10.

Greenberg, M. S. and Shapiro, S. P. (1971), "Indebtedness: An adverse aspect of asking for and receiving help", Sociometry, Vol. 34, pp. 290-301.

Hall, C. M., Sharples, L., Cambourne, B. and Macionis, N. (2000), Wine tourism around the world: Development, management and markets. Butterworth Heinemann, Woburn, MA

Hoelter, J. W. (1983), "The effect of role evaluation and commitment on identity salience", Social Psychology Quarterly, Vol. 46 No. 2, pp. 140-47.

Laverie, D. A. (1998), "Motivations for ongoing participation in a fitness activity", Leisure Sciences, Vol. 20, pp. 277-302.

Laverie, D. A. and Arnett, D. B. (2000), "Factors affecting fan attendance: The influence of identity salience and satisfaction", Journal of Leisure Research, Vol. 32 No. 2, pp. 225 46.

Laverie, D. A., Kleine, R. E. and Kleine Schultz, S. (2002), "Re-inquiries - reexamination and extension of Kleine, Kleine, and Kernan's social identity model of mundane consumption: The mediating role of the appraisal process", Journal of Consumer Research, Vol. 28 No. 4, pp. 659-69.

Lockshin, L., Quester, P. and Spawton, A. L. (2001), "Segmentation by involvement or nationality for global retailing: A cross-national comparative study of wine shopping behaviours", Journal of Wine Research, Vol. 12 No. 3, pp. 223-36. 
Lockshin, L., Spawton, A. L. and Macintosh, G. (1997), "Using product, brand, and purchasing involvement for retail segmentation", Journal of Retailing and Consumer Services, Vol. 4 No. 3, pp. 171-83.

Lynn, M. and Grassman, A. (1990), "Restaurant tipping: An examination of three "rational' explanations", Journal of Economic Psychology, Vol. 11 No. 2, pp. 169-81.

Lynn, M. and Graves, J. (1996), "Tipping: An incentive/reward for service?" Journal of Hospitality \& Tourism Research, Vol. 20 No. 1, pp. 1-14.

Macionis, N. and Cambourne, B. (1998), "Wine tourism: Just what is it about?" Australian and New Zealand Wine Industry Journal, Vol. 13 No. 1, pp. 41-47.

Mitchell, R., Hall, C. M. and McIntosh, A. (2000),"Wine tourism and consumer behavior." in Hall, C. M., Sharples, L., Cambourne, B. and Macionis, N. (Eds.), Wine tourism around the world: Development, management, and markets, Butterworth-Heinemann, Woburn, MA, pp. 115-35.

Mittal, B. (1995), "A comparative analysis of four scales of consumer involvement", Psychology and Marketing, Vol. 12 No. 7, pp. 663-82.

Motto Kryla \& Fisher, L., (2006), Economic impact of California wine. The Wine Business Center, St. Helena, CA.

Moulton, K. S. and Lapsley, J. T. (2001), Successful wine marketing. Aspen Publishers, Gaithersburg: MD

Park, C. W., Mothersbaugh, D. L. and Feick, L. (1994), "Consumer knowledge assessment", Journal of Consumer Research, Vol. 21 No. 1, pp. 71-82.

Quester, P. G. and Smart, J. (1998), "The influence of consumption situation and product involvement over consumers' use of product attribute", Journal of Consumer Marketing, Vol. 15 No. 3, pp. 220-38.

Raju, P. S., Lonial, S. C. and Mangold, W. G. (1995), "Differential effects of subjective knowledge, objective knowledge, and usage experience on decision making", Journal of Consumer Psychology, Vol. 4 No. 2, pp. 153-80.

Rust, R. T., Zeithaml, V. A. and Lemon, K. N. (2000), Driving customer equity: How customer lifetime value is reshaping corporate strategy. Free Press, New York, NY

Shamir, B. (1992), "Some correlates of leisure identity salience: Three exploratory studies", Journal of Leisure Research, Vol. 24 No. 4, pp. 301-23.

Spawton, A. L. (1991), "Grapes and wine seminar - prospering in the 1990s: Changing your view of the consumer", International Marketing Review, Vol. 8 No. 4, pp. 32-43. 
Spawton, A. L. (1986), "Marketing planning for small wineries", Australian and New Zealand Wine Industry Journal, Vol. 1 No. 3, pp. 54-57.

Stryker, S. (1968), " Identity salience and role performance: The relevance of symbolic interaction theory for family research", Journal of Marriage and the Family, Vol. 4, pp. $558-64$

Stryker, S. (1980), Symbolic interactionism: A social structural version. Benjamin Cummings Pub. Co., Menlo Park: CA.

Texas Wine Marketing Research Institute (2007). The economic impact of wine and grapes on the state of Texas 2007, available at: www.hs.ttu.edu/texaswine/2007/TX_ECONOMIC_IMPACT_2007.pdf.

U.S. Census Bureau (2006). Income, poverty and health insurance coverage in the United States: 2005, available at: http://www.census.gov/prod/2006pubs/p60-231.pdf.

Wansink, B., Cordua, G., Blair, E., Payne, C. and Geiger, S. (2006), "Wine promotions in restaurants", Cornell Hotel and Restaurant Administration Quarterly, Vol. 47 No. 4, pp. $327-36$.

Whatley, M. A., Webster, J. M., Smith, R. H. and Rhodes, A. (1999), "The effect of a favor on public and private compliance: How internalized is the norm of reciprocity?" Basic and Applied Social Psychology, Vol. 21 No. 3, pp. 251-59.

Wine Institute (2004). California wine has $\$ 45.4$ billion economic impact on state, available at: $\mathrm{http} / /$ www.wineinstitute.org/communications/statistics/Economic\%20Impact\%20Report $\% 202004 . h t m$.

Winemakers Federation of Australia (2005). A recipe for success: Wine and tourism blend for regional prosperity., available at: http://www.wfa.org.au/PDF/press18.05.05.pdf.

Yuan, J., Cai, L. A., Morrison, A. M. and Linton, S. (2005), "An analysis for wine festival attendees' motivations: A synergy of wine, travel, and special events?" Journal of Vacation Marketing, Vol. 11 No. 1, pp. 37-54.

Zaichkowsky, J. L. (1985), "Measuring the involvement construct", Journal of Consumer Research, Vol. 12 No. 3, pp. 341-52. 
Table I

Summary for hierarchical multiple regression analysis for predicting purchasing at wineries

\begin{tabular}{cccccccc}
\hline Step & $R^{2}$ & Adjusted $R^{2}$ & $R^{2}$ change & $F$ change & $d f 1$ & $d f 2$ & $\begin{array}{c}\text { Significance } \\
F \text { change }\end{array}$ \\
\hline 1 & .12 & .11 & .12 & 12.28 & 4 & 351 & $.00^{* *}$ \\
2 & .36 & .35 & .24 & 64.60 & 2 & 349 & $.00^{* *}$ \\
\hline
\end{tabular}

Note: $* * p<.01$

1. Predictors: product involvement, purchase involvement, knowledge, identity.

2. Predictors: product involvement, purchase involvement, knowledge, identity, gratitude, obligation. 
Table II

Coefficients for predictors of purchasing at wineries

\begin{tabular}{llcccc}
\hline Step & Predictor Variables & $B$ & SE B & Beta & $p$ \\
\hline 1 & Product Involvement & 3.44 & 1.57 & .18 & $.03^{*}$ \\
& Purchase Involvement & 2.00 & 1.11 & .10 & $.04^{*}$ \\
& Knowledge & 3.39 & 1.55 & .17 & $.03^{*}$ \\
& Identity & -1.03 & 1.54 & -.05 & .50 \\
\hline 2 & Product Involvement & 2.79 & 1.36 & .14 & $.04^{*}$ \\
& Purchase Involvement & 2.17 & .96 & .11 & $.02^{*}$ \\
& Knowledge & 2.82 & 1.33 & .14 & $.04^{*}$ \\
& Identity & -.14 & 1.32 & -.01 & .92 \\
& Gratitude & 6.09 & 1.05 & .34 & $.00^{* *}$ \\
& Obligation & 4.79 & 1.25 & .22 & $.00^{* *}$ \\
\hline
\end{tabular}

Note: $* p<.05 . * * p<.01$. 